\title{
Streptomyces zinciresistens sp. nov., a zinc-resistant actinomycete isolated from soil from a copper and zinc mine
}

\author{
Yan Bing Lin, Xin Ye Wang, Hui Fen Li, Na Na Wang, Hu Xuan Wang, \\ Ming Tang and Ge-Hong Wei \\ College of Life Sciences, Shaanxi Key Laboratory of Molecular Biology for Agriculture, Northwest A \\ \& F University, Yangling, Shaanxi 712100, PR China
}

Correspondence

Ge Hong Wei

weigehong@yahoo.com.cn
Heavy metal contamination is a serious problem worldwide. Increasing numbers of environmental micro-organisms are being studied as possible remediation agents for heavy metal contamination (Thompson \& Watling, 1987; Smith et al., 1994; Poopal \& Laxman, 2009). The effects of heavy metals on a range of species belonging to the genus Streptomyces have been reported by Abbas \& Edwards (1989). Despite being reported to be susceptible to heavy metals (Lugauskas et al., 2005), little is known about the presence of actinomycetes in soils contaminated with heavy metals, especially zinc. Zinc is an essential metal for the normal growth and development of organisms since it is a constituent of many enzymes and proteins. Although it is an essential trace element for animals, plants and microorganisms, zinc is toxic to organisms at millimolar concentrations (Barceloux, 1999). Strain CCNWNQ 0016 exhibited a higher degree of resistance to $\mathrm{Zn}^{2+}$ than previously reported strains (Wani et al., 2007, 2008; Li et al., 2010). The strain will be used for further investigation into the bioremediation of zinc-contaminated environments.

The GenBank/EMBL/DDBJ accession number for the $16 \mathrm{~S}$ rRNA gene sequence of strain CCNWNQ $0016^{\top}$ is GU225938.

A supplementary table is available with the online version of this paper.
Strain CCNWNQ $0016^{\mathrm{T}}$ was isolated using the dilution plating method from a sample of zinc- and copperpolluted soil collected from Ningqiang (106 $16^{\circ} 37.9^{\prime \prime} \mathrm{E}$ $33^{\circ} 01^{\prime} 13.5^{\prime \prime} \mathrm{N}$ and an altitude of $\left.669 \mathrm{~m}\right)$, Shaanxi province, north-western China, in July 2006. The zinc concentration of the soil sample was $1216.7 \mathrm{mg} \mathrm{kg}^{-1}$. The isolation medium used was modified Gause's synthetic agar medium (16.0 g soluble starch, $4.0 \mathrm{~g}$ D-glucose, $1.0 \mathrm{~g}$ potassium nitrate, $0.5 \mathrm{~g}$ potassium phosphate dibasic trihydrate, $0.5 \mathrm{~g}$ magnesium sulfate heptahydrate, $0.001 \mathrm{~g}$ ferrous sulfate heptahydrate, $0.5 \mathrm{~g}$ sodium chloride, $20 \mathrm{~g}$ agar powder, $0.5 \mathrm{mg}$ vitamin B compound and $1000 \mathrm{ml}$ distilled water, $\mathrm{pH} 7.2$ ). The vitamin $\mathrm{B}$ compound contained $0.5 \mathrm{mg}$ nicotinic acid, $0.5 \mathrm{mg}$ vitamin $\mathrm{B}_{6}, 0.5 \mathrm{mg}$ lactoflavin, $0.5 \mathrm{mg}$ inositol and $0.25 \mathrm{mg}$ biotin (Guo et al., 2009). The isolate was maintained on modified Gause's synthetic agar slopes and as glycerol suspensions (20\%, $\mathrm{v} / \mathrm{v}$ ) at $-20{ }^{\circ} \mathrm{C}$. Biomass for most of the chemotaxonomic and molecular systematic studies was harvested after incubation in shake flasks of modified Gause's broth at $28{ }^{\circ} \mathrm{C}$ for $4-7$ days.

Morphological properties were examined by light microscopy (Olympus CX31) and scanning electron microscopy (JSM 6360LV). Colours were determined by the methods described by Kelly (1964). 
The diaminopimelic acid isomer and the whole-cell sugar composition were analysed using TLC according to procedures described by Lechevalier \& Lechevalier (1980). Menaquinones were extracted and determined by HPLC using the methods of Collins (1985). Phospholipid analysis was carried out according to the method of Lechevalier et al. (1981). Fatty acids were extracted as described by Kämpfer \& Kroppenstedt (1996). The DNA G + C content was determined using the thermal melting protocol (Marmur \& Doty, 1962) with Escherichia coli K-12 as the standard. DNA-DNA relatedness was determined in triplicate by the initial renaturation rate method (De Ley et al., 1970).

Strain CCNWNQ $0016^{\mathrm{T}}$ was examined for a range of chemotaxonomic and physiological properties following the methods of Williams et al. (1983). International Streptomyces Project (ISP) media were used to determine the colour of diffusible pigments and the utilization of sole carbon and nitrogen sources (Shirling \& Gottlieb, 1966). Temperature $\left(20,28,37\right.$ and $\left.45{ }^{\circ} \mathrm{C}\right)$ and $\mathrm{pH}(5-12$, incubated at $28{ }^{\circ} \mathrm{C}$ ) tolerances were determined on Bennett's agar plates after incubation for 2 weeks.

Genomic DNA extraction and PCR amplification of the 16S rRNA gene were carried out following the procedures of Chun \& Goodfellow (1995). Universal bacterial $16 \mathrm{~S}$ rRNA gene primers [forward primer P1 (5'-CGGGATCCAGAGTTTGATCCTGGCTCAGAACGAACGCT-3') and reverse primer P6 (5'-CGGGATCCTACGGCTACCTTGTTACGACTTCACCCC-3')] were used for 16S rRNA gene amplification. The PCR product was purified and sequenced directly using an automated DNA sequencing system (ABI 3730XL). The 16S rRNA gene sequence of the strain was aligned using CLUSTAL X version 1.8 (Thompson et al., 1997) with almost complete $16 \mathrm{~S}$ rRNA gene sequences of type strains of recognized species of the genus Streptomyces obtained from GenBank/EMBL/DDBJ. A phylogenetic tree was reconstructed using the neighbour-joining (Saitou \& Nei, 1987), minimum-evolution (Rzhetsky \& Nei, 1993) and maximum-parsimony (Fitch, 1971) methods in the TREECON software package version 1.3b (Van de Peer \& De Wachter, 1994) and the MEGA3.1 software package (Kumar et al., 2004). Genetic distance matrices were estimated by the Kimura two-parameter model (Kimura, 1980). Tree topology was evaluated by bootstrap analysis based on 1000 replicates (Felsenstein, 1985).

The chemotaxonomic and morphological properties of strain CCNWNQ $0016^{\mathrm{T}}$ were consistent with those of members of the genus Streptomyces (Williams et al., 1989). The isolate formed a highly branched substrate mycelium and aerial hyphae which differentiated into spiral spore chains with spiny spores (Fig. 1). Growth of the organism was moderate on ISP media 2, 4 and 5, and nutrient agar, but poor on ISP medium 3. The colour of the aerial mycelium was light grey-white to greenish-grey and the substrate mycelium was light grey-white to light yellow. Diffusible pigments were not produced on any of the

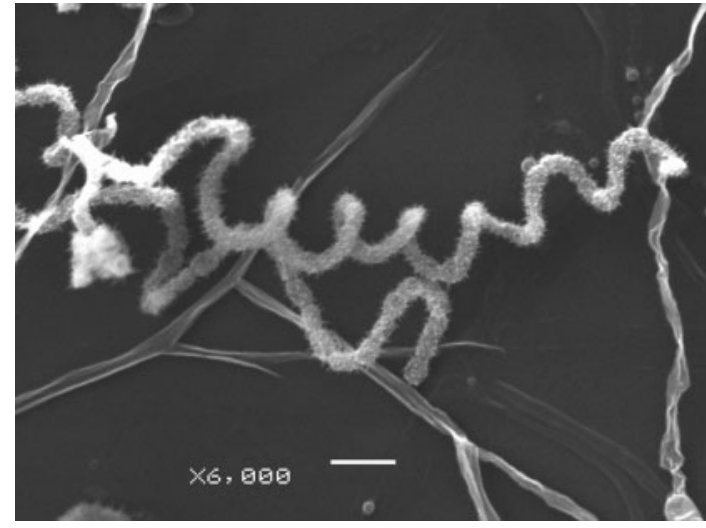

Fig. 1. Scanning electron micrograph of the spiral spore chains and spiny spores of strain CCNWNQ $0016^{\top}$ after 15 days at $28{ }^{\circ} \mathrm{C}$ on modified Gause's synthetic agar medium. Bar, $2 \mu \mathrm{m}$.

media tested (Supplementary Table S1, available in IJSEM Online).

The whole cell hydrolysate contained LL-diaminopimelic acid. Hexa- and octa-hydrogenated menaquinones with nine isoprene units $\left[\mathrm{MK}-9\left(\mathrm{H}_{6}, \mathrm{H}_{8}\right)\right]$ were the predominant menaquinones and diphosphatidylglycerol, phosphatidylethanolamine, phosphatidylinositol and phosphatidylinositol mannosides were the major polar lipids (phospholipid

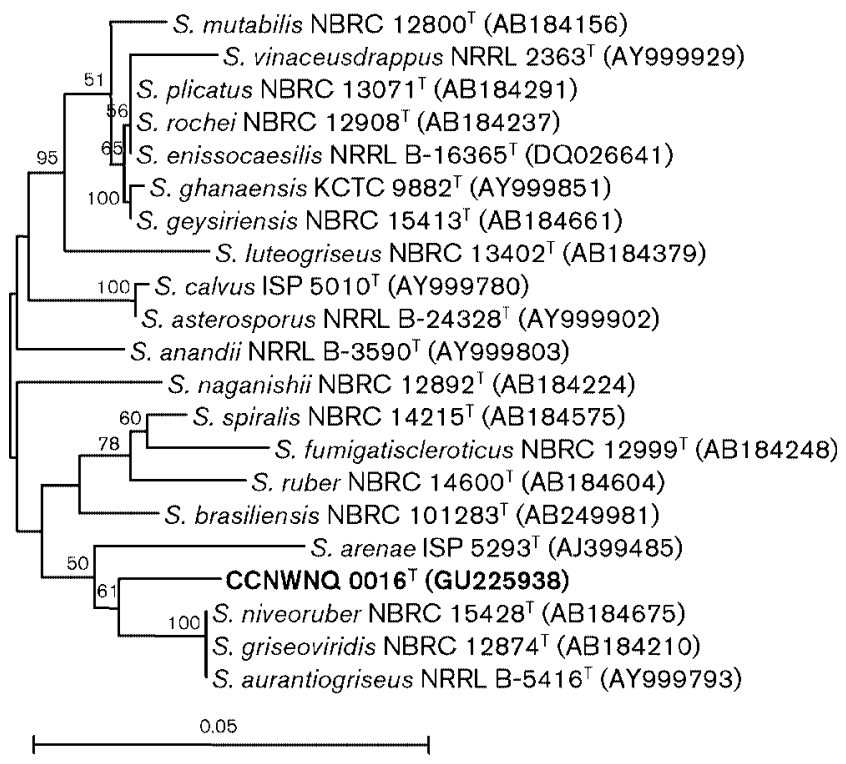

Fig. 2. Unrooted neighbour-joining phylogenetic tree based on almost complete 16S rRNA gene sequences showing the relationship between strain CCNWNQ $0016^{\top}$ and related species in the genus Streptomyces. Accession numbers are given in parentheses. Bootstrap percentages (based on 1000 replications) are shown at the branch points; only values above $50 \%$ are given. Bar, 0.05 substitutions per nucleotide position. 
Table 1. Phenotypic characteristics of strain CCNWNQ $0016^{\top}$ and the most closely related species of the genus Streptomyces

Strains: 1, Streptomyces zinciresistens sp. nov. CCNWNQ $0016^{\mathrm{T}} ; 2$, S. niveoruber NBRC $15428^{\mathrm{T}} ; 3$, S. griseoviridis $\mathrm{NBRC}_{12874^{\mathrm{T}}}$; 4, S. aurantiogriseus NBRC $12842^{\mathrm{T}}$. All strains are positive for assimilation of D-galactose and D-glucose as sole carbon sources and for assimilation of L-phenylalanine, L-valine and L-tyrosine as sole nitrogen sources. All strains degrade Tweens 40, 60 and 80 and grow with $4 \% \mathrm{NaCl}$, but not with $8 \% \mathrm{NaCl}$. All strains grow at $28-37{ }^{\circ} \mathrm{C}$ and $\mathrm{pH} 7-9$. All strains are positive for nitrate reduction and starch hydrolysis. +, Positive; - , negative; $(+)$, weakly positive. All data were determined in the present study.

\begin{tabular}{|c|c|c|c|c|}
\hline Characteristics & 1 & 2 & 3 & 4 \\
\hline \multicolumn{5}{|l|}{ Culture characteristics: } \\
\hline $\begin{array}{l}\text { Aerial mycelium colour on Gause's } \\
\text { synthetic agar }\end{array}$ & Grey to greenish-grey & Ivory & Pale greyish-purple & Flaxen \\
\hline $\begin{array}{l}\text { Substrate mycelium colour on } \\
\text { Gause's synthetic agar }\end{array}$ & Greyish-yellow & Pale yellow & Purplish-red & Apricot yellow \\
\hline Spore chain morphology & Spiral & Straight & Rectiflexibiles & Rectiflexibiles/spiral \\
\hline Production of diffusible pigments & None & Brown & None & None \\
\hline \multicolumn{5}{|c|}{ Assimilation of sole carbon sources ( $1.0 \%, \mathrm{w} / \mathrm{v}$, except where marked): } \\
\hline D-Sorbitol & + & $(+)$ & + & - \\
\hline Lactose & + & $(+)$ & + & + \\
\hline myo-Inositol & + & $(+)$ & + & + \\
\hline Sucrose & + & + & + & $(+)$ \\
\hline Maltose & + & + & + & $(+)$ \\
\hline L-Rhamnose & + & $(+)$ & + & + \\
\hline D-Fructose & - & + & + & + \\
\hline L-Arabinose & $(+)$ & + & $(+)$ & + \\
\hline D-Xylose & - & + & + & + \\
\hline Trehalose & + & $(+)$ & + & + \\
\hline Dextrin & - & + & + & + \\
\hline Sodium acetate $(0.1 \%)$ & - & + & + & + \\
\hline \multicolumn{5}{|c|}{ Assimilation of sole nitrogen sources $(1.0 \%, \mathrm{w} / \mathrm{v})$ : } \\
\hline L-Isoleucine & - & $(+)$ & - & $(+)$ \\
\hline L-Cysteine & - & - & + & $(+)$ \\
\hline L-Aspartic acid & + & - & - & - \\
\hline \multicolumn{5}{|l|}{ Decomposition of: } \\
\hline Adenine & - & - & + & + \\
\hline Xanthine & - & - & + & + \\
\hline Tween 20 & - & + & + & + \\
\hline \multicolumn{5}{|l|}{ Growth at: } \\
\hline $45^{\circ} \mathrm{C}$ & - & - & + & + \\
\hline $\mathrm{pH} 5$ & + & - & + & - \\
\hline pH 12 & - & - & + & + \\
\hline \multicolumn{5}{|l|}{ Growth with: } \\
\hline $7 \% \mathrm{NaCl}$ & + & - & + & + \\
\hline $0.1 \%$ Phenol & - & + & + & + \\
\hline $0.01 \% \mathrm{NaNO}_{3}$ & $(+)$ & - & $(+)$ & - \\
\hline Gelatin liquefaction & + & $(+)$ & + & + \\
\hline Milk coagulation & + & + & - & - \\
\hline Milk peptonization & - & - & + & + \\
\hline $\mathrm{H}_{2} \mathrm{~S}$ production & + & - & - & - \\
\hline Melanin production & $(+)$ & + & - & - \\
\hline \multicolumn{5}{|l|}{ Heavy metal resistance } \\
\hline $\mathrm{Zn}^{2+}(20 \mathrm{mM})$ & + & - & - & - \\
\hline $\mathrm{Zn}^{2+}(35 \mathrm{mM})$ & + & - & - & - \\
\hline $\mathrm{Cu}^{2+}(0.2 \mathrm{mM})$ & + & - & - & - \\
\hline $\mathrm{Cd}^{2+}(0.5 \mathrm{mM})$ & + & - & - & - \\
\hline
\end{tabular}


type II sensu Lechevalier et al., 1977). There were no characteristic whole-cell sugars or mycolic acids. Analysis of the major fatty acids showed that the organism mainly contained saturated fatty acids such as anteiso- $\mathrm{C}_{15: 0}$ $(20.76 \%), \mathrm{C}_{16: 0}(19.25 \%)$ and iso- $\mathrm{C}_{16: 0}(10.92 \%)$, with a small proportion of unsaturated fatty acids.

The 16S rRNA gene sequence (1460 nt) of strain CCNWNQ $0016^{\mathrm{T}}$ was aligned with $16 \mathrm{~S}$ rRNA gene sequences of other species of the genus Streptomyces. The isolate was found to be most closely related to Streptomyces niveoruber NBRC $15428^{\mathrm{T}}$, Streptomyces griseoviridis $\mathrm{NBRC} 12874^{\mathrm{T}}$ and Streptomyces aurantiogriseus NBRC $12842^{\mathrm{T}}$ with sequence similarities of 98.8, 98.7 and $98.7 \%$, respectively (Fig. 2).

DNA-DNA relatedness studies were carried out between strain CCNWNQ $0016^{\mathrm{T}}$ and the most closely related type strains, i.e. S. niveoruber NBRC $15428^{\mathrm{T}}$, S. griseoviridis NBRC $12874^{\mathrm{T}}$ and S. aurantiogriseus NBRC $12842^{\mathrm{T}}$. DNADNA relatedness values were $49.6 \pm 0.6,47.2 \pm 0.9$ and $46.9 \pm 1.1 \%$, respectively, which were significantly lower than the $70 \%$ cut-off point recommended for the delineation of genomic species (Wayne et al., 1987).

Phenotypic characterization of strain CCNWNQ $0016^{\mathrm{T}}$ showed clearly that it differed from the three most closely related species (Table 1). Moreover, a combination of physiological and biochemical characteristics enabled strain CCNWNQ $0016^{\mathrm{T}}$ to be distinguished from its closest phylogenetic neighbours.

Strain CCNWNQ $0016^{\mathrm{T}}$ grew well in SC liquid medium (10 g soluble starch, $1.0 \mathrm{~g}$ casein, $0.5 \mathrm{~g} \mathrm{~K}_{2} \mathrm{HPO}_{4}, 15.0 \mathrm{~g}$ agar and $1000 \mathrm{ml}$ distilled water, $\mathrm{pH}$ 7.2) supplemented with $20 \mathrm{mM} \mathrm{Zn}^{2+}\left(\mathrm{ZnCl}_{2}\right)$ and visible growth was observed in the presence of $35 \mathrm{mM} \mathrm{Zn}^{2+}$. In contrast, $S$. niveoruber NBRC $15428^{\mathrm{T}}$, S. griseoviridis NBRC $12874^{\mathrm{T}}$ and S. aurantiogriseus NBRC $12842^{\mathrm{T}}$ could not grow in the presence of $20 \mathrm{mM}$ $\mathrm{Zn}^{2+}$. The maximum level of resistance to $\mathrm{Zn}^{2+}$ for strain CCNWNQ $0016^{\mathrm{T}}$ was $35 \mathrm{mM}$.

Taken together, all the genotypic and phenotypic data suggest that strain CCNWNQ $0016^{\mathrm{T}}$ represents a novel species of the genus Streptomyces, for which the name Streptomyces zinciresistens sp. nov. is proposed.

\section{Description of Streptomyces zinciresistens sp. nov.}

Streptomyces zinciresistens (zin.ci.re.sis'tens. L. n. zincum zinc; L. part. adj. resistens resisting; N.L. part. adj. zinciresistens zinc-resisting, referring to the organism's ability to resist zinc).

Aerobic, Gram-positive, zinc-resistant actinomycete that develops a well-branched grey-white to greenish-grey aerial mycelium and a greyish-yellow to light brown substrate mycelium on Gause's synthetic agar and ISP medium 2. Produces spiral spore chains with spiny, greyish-green spores. No diffusible pigment is formed on any of the tested media. Growth occurs at $20-37{ }^{\circ} \mathrm{C}$, at $\mathrm{pH} 5.0-11.0$ and in the presence of $4-7 \%(\mathrm{w} / \mathrm{v}) \mathrm{NaCl}$. Optimum growth occurs at $28{ }^{\circ} \mathrm{C}$, at $\mathrm{pH} 7.5$ and in the presence of $4 \%(\mathrm{w} / \mathrm{v}) \mathrm{NaCl}$. Physiological and biochemical profiles, including those relating to carbon source utilization, biodegradation and growth, are listed in Table 1. Chemotaxonomic properties are typical of the genus Streptomyces.

The type strain is CCNWNQ $0016^{\mathrm{T}}\left(=\mathrm{K} 42^{\mathrm{T}}=\mathrm{ACCC}\right.$ $41871^{\mathrm{T}}=$ HAMBI $3107^{\mathrm{T}}$ ), isolated from a zinc-contaminated soil sample collected from Shaanxi province, northwestern China. The DNA G $+\mathrm{C}$ content of the type strain is $70.3 \mathrm{~mol} \%$.

\section{Acknowledgements}

This work was supported by projects from the National Science Foundation of China (30970003, 30900215 and 30630054), National Basic Research Program of China (2010CB126502) and PCSIRT (IRT0748) of China.

\section{References}

Abbas, A. \& Edwards, C. (1989). Effects of metals on a range of Streptomyces species. Appl Environ Microbiol 55, 2030-2035.

Barceloux, D. G. (1999). Zinc. J Toxicol Clin Toxicol 37, 279-292.

Chun, J. \& Goodfellow, M. (1995). A phylogenetic analysis of the genus Nocardia with $16 \mathrm{~S}$ rRNA gene sequences. Int J Syst Bacteriol 45, 240-245.

Collins, M. D. (1985). Isoprenoid quinone analysis in classification and identification. In Chemical Methods in Bacterial Systematics, pp. 267-287. Edited by M. Goodfellow \& D. E. Minnikin. London: Academic Press.

De Ley, J., Cattoir, H. \& Reynaerts, A. (1970). The quantitative measurement of DNA hybridization from renaturation rates. Eur $J$ Biochem 12, 133-142.

Felsenstein, J. (1985). Confidence limits on phylogenies: an approach using the bootstrap. Evolution 39, 783-791.

Fitch, W. M. (1971). Toward defining the course of evolution: minimum change for a specific tree topology. Syst Zool 20, 406-416.

Guo, J. K., Lin, Y. B., Zhao, M. L., Sun, R., Wang, T. T., Tang, M. \& Wei, G. H. (2009). Streptomyces plumbiresistens sp. nov., a lead-resistant actinomycete isolated from lead-polluted soil in north-west China. Int J Syst Evol Microbiol 59, 1326-1330.

Kämpfer, P. \& Kroppenstedt, R. M. (1996). Numerical analysis of fatty acid patterns of coryneform bacteria and related taxa. Can J Microbiol 42, 989-1005.

Kelly, K. L. (1964). Inter-Society Color Council - National Bureau of Standards Color Name Charts Illustrated with Centroid Colors. Washington, DC: US Government Printing Office.

Kimura, M. (1980). A simple method for estimating evolutionary rates of base substitutions through comparative studies of nucleotide sequences. J Mol Evol 16, 111-120.

Kumar, S., Tamura, K. \& Nei, M. (2004). MEGA3: integrated software for molecular evolutionary genetics analysis and sequence alignment. Brief Bioinform 5, 150-163.

Lechevalier, H. A. \& Lechevalier, M. P. (1980). The chemotaxonomy of actinomycetes. In Actinomycete Taxonomy (SIM Special Publication no. 6), pp. 277-284. Edited by A. Dietz \& D. W. Thayer. Arlington, VA: Society for Industrial Biology. 
Lechevalier, M. P., De Bièvre, C. \& Lechevalier, H. A. (1977). Chemotaxonomy of aerobic actinomycetes: phospholipid composition. Biochem Syst Ecol 5, 249-260.

Lechevalier, M. P., Stern, A. E. \& Lechevalier, H. A. (1981). Phospholipids in the taxonomy of actinomycetes. Zentralbl Bakteriol Hyg Abt 1 ((Suppl. 11), ), 111-116.

Li, H. F., Lin, Y. B., Guan, W. M., Chang, J. L., Xu, L., Guo, J. K. \& Wei, G. H. (2010). Biosorption of $\mathrm{Zn}(\mathrm{II})$ by live and dead cells of Streptomyces ciscaucasicus strain CCNWHX 72-14. J Hazard Mater 179, 151-159.

Lugauskas, A., Levinskaitë, L., Peèiulytë, D., Repeèkienë, J., Motuzas, A., Vaisvalavièius, R. \& Prosyèevas, I. (2005). Effect of copper, zinc and lead acetates on microorganisms in soil. Ekologija 1, 61-69.

Marmur, J. \& Doty, P. (1962). Determination of the base composition of deoxyribonucleic acid from its thermal denaturation temperature. J Mol Biol 5, 109-118.

Poopal, A. C. \& Laxman, R. S. (2009). Studies on biological reduction of chromate by Streptomyces griseus. J Hazard Mater 169, 539-545.

Rzhetsky, A. \& Nei, M. (1993). Theoretical foundation of the minimum-evolution method of phylogenetic inference. Mol Biol Evol 10, 1073-1095.

Saitou, N. \& Nei, M. (1987). The neighbor-joining method: a new method for reconstructing phylogenetic trees. Mol Biol Evol 4, 406-425.

Shirling, E. B. \& Gottlieb, D. (1966). Methods for characterization of Streptomyces species. Int J Syst Bacteriol 16, 313-340.

Smith, L. A., Alleman, B. C. \& Copley-Graves, L. (1994). Biological treatment options. In Emerging Technology for Bioremediation of Metals, pp. 1-12. Edited by J. L. Means \& R. E. Hinchee. New York: Lewis Publishers.
Thompson, G. A. \& Watling, R. J. (1987). Bioaccumulation potential of heterotrophic bacteria for lead, selenium, and arsenic. Bull Environ Contam Toxicol 38, 1049-1054.

Thompson, J. D., Gibson, T. J., Plewniak, F., Jeanmougin, F. \& Higgins, D. G. (1997). The CLUSTAL_X windows interface: flexible strategies for multiple sequence alignment aided by quality analysis tools. Nucleic Acids Res 25, 4876-4882.

Van de Peer, Y. \& De Wachter, R. (1994). TREECON for Windows: a software package for the construction and drawing of evolutionary trees for the Microsoft Windows environment. Comput Appl Biosci 10, 569-570.

Wani, P. A., Khan, M. S. \& Zaidi, A. (2007). Effect of metal tolerant plant growth promoting Bradyrhizobium sp. (vigna) on growth, symbiosis, seed yield and metal uptake by greengram plants. Chemosphere 70, 36-45.

Wani, P. A., Khan, M. S. \& Zaidi, A. (2008). Impact of zinc-tolerant plant growth-promoting rhizobacteria on lentil grown in zincamended soil. Agron Sustain Dev 28, 449-455.

Wayne, L. G., Brenner, D. J., Colwell, R. R., Grimont, P. A. D., Kandler, O., Krichevsky, M. I., Moore, L. H., Moore, W. E. C., Murray, R. G. E. \& other authors (1987). International Committee on Bacterial Systematics. Report of the ad hoc committee on reconciliation of approaches to bacterial systematics. Int J Syst Bacteriol 37, 463-464.

Williams, S. T., Goodfellow, M., Alderson, G., Wellington, E. M. H., Sneath, P. H. A. \& Sackin, M. J. (1983). Numerical classification of Streptomyces and related genera. J Gen Microbiol 129, 1743-1813.

Williams, S. T., Goodfellow, M. \& Alderson, G. (1989). Genus Streptomyces Waksman and Henrici 1943, 339 ${ }^{\mathrm{AL}}$. In Bergey's Manual of Systematic Bacteriology, vol. 4, pp. 2452-2492. Edited by S. T. Williams, M. E. Sharpe \& J. G. Holt. Baltimore: Williams \& Wilkins. 